\title{
First Successful Haploidentical Stem Cell Transplantation in Romania
}

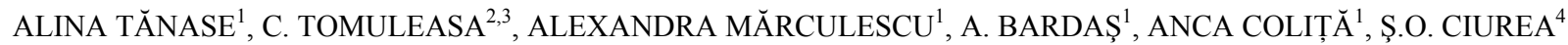 \\ ${ }^{1}$ Department of Stem Cell Transplantation, Fundeni Clinical Institute, Bucharest, Romania \\ ${ }^{2}$ Department of Hematology, Ion Chiricuta Oncology Institute, Cluj-Napoca, Romania \\ 3،"Iuliu Hațieganu" University of Medicine and Pharmacy, Cluj-Napoca, Romania \\ ${ }^{4}$ Division of Cancer Medicine, Department of Stem Cell Transplantation, \\ The University of Texas MD Anderson Cancer Center, Houston, TX, United States of America
}

\begin{abstract}
Hematopoietic stem cell transplantation is an established treatment for many malignant and non-malignant haematological disorders. In the current case report, we describe the first haploidentical stem cell transplantation, used for the first time in Romania, the case of a 33 year-old young woman diagnosed with Hodgkin's lymphoma that has underwent a haploSCT after she relapsed from several chemotherapy regimens, as well as after an autologous stem cell transplantation. This success represents a prèmiere in Romanian clinical hematology, being the first case of a haploSCT in Romania, as well as in South-Eastern Europe.
\end{abstract}

Key words: haploidentical stem cell transplantation, Hodgkin's lymphoma, first case in Romania.

\section{INTRODUCTION}

Hematopoietic stem cell transplantation (SCT) is an established treatment for many malignant and non-malignant haematological disorders. More than 30.000 SCTs are currently performed each year in the Western world $[1,2]$. The first SCT was performed more than 50 years ago. Ever since, this therapy has been used for the treatment of various conditions that include congenital or acquired bone marrow failure, as well as hematological malignancies such as leukemias, lymphomas or multiple myelomas [3]. Cure from a hematological malignancy is believed to rely on exploiting the graft-versus-leukemia (GVL) effects by allogeneic immune cells in addition to the effects by conditioning regimen $[4,5]$.

In the current case report, we describe the very same technique used for the first time in Romania, the case of a 33 year-old young woman that has underwent a haploSCT after she relapsed from several chemotherapy regimens, as well as after an autologous stem cell transplantation. This success represents a prèmiere in Romanian clinical hematology, being the first case of a haploSCT in Romania, as well as in South-Eastern Europe.

\section{CASE REPORT}

\section{DIAGNOSIS AND PREVIOUS TREATMENT}

A 27-year old young woman was diagnosed in February 2009 with stage IIIB nodular sclerosing
Hodgkin's lymphoma (HL). Staging revealed a large mediastinal mass of approximately $10 \mathrm{~cm}$ in diameter with multiple metastatic lymph nodes localized around the mesenteric artery, the hepatic hilum, as well as the lombo-aortic artery and the common iliac arteries, as seen in Figure 1. Following diagnosis, three cycles of chemotherapy with adriamycin, bleomycin, vinblastine and dacarbazine (ABVD) were given, according to the protocols of Canellos et al. [6]. As sub-diaphragmatic metastatic lymph nodes and a persistent mediastinal mass were diagnosed on the computer tomography (CT) scan, as seen in Figures $2 \mathrm{~A}$ and $\mathrm{B}$, a diagnosis of partial remission was concluded. Thus, the therapy was changed to escalated-dose BEACOPP (bleomycin, etoposide, adriamycin, cyclophosphamide, vincristine, procarbazine and prednisone), according to Diehl et al. [7]. After 4 chemotherapy cycles, a complete remission was diagnosed on a positron emission tomography (PET scan).

One year later, a relapse was treated with 3 cycles of salvage therapy with ifosfamide, gemcitabine and vinorelbine (IGEV), according to the study of Santoro et al. [8]. After IGEV chemotherapy, the patient refused an autologous stem cell transplantation. A PET Scan showed a complete remission, followed by yet another relapse one year later (Figure 3), treated with 3 cycles of dexamethasone, high dose cytarabine and cisplatin (DHAP) [9]. The 3 cycles of DHAP were followed by an autologous stem cell transplantation, with BEAM conditioning chemotherapy (high-dose carmustine, etoposide, cytarabine and melphalan), as described by the 
same German Hodgkin Lymphoma Study Group [10]. Another PET Scan, done 100 days after the autologous stem cell transplantation (autoSCT), showed an increased metabolic activity in various sub-diaphragmatic lymph nodes, as well as in the left iliac crest, as seen in Figure 4. Salvage radio- therapy with 30 Gy was later on done on the left hemi-pelvis [11], but 6 months later another positive PET Scan showed active disease in the sub-diaphragmatic lymph nodes, confirmed later on by new bone lesions in the ischium, pubis and vertebrae (Figures $5 \mathrm{~A}$ to $\mathrm{C}$ ).

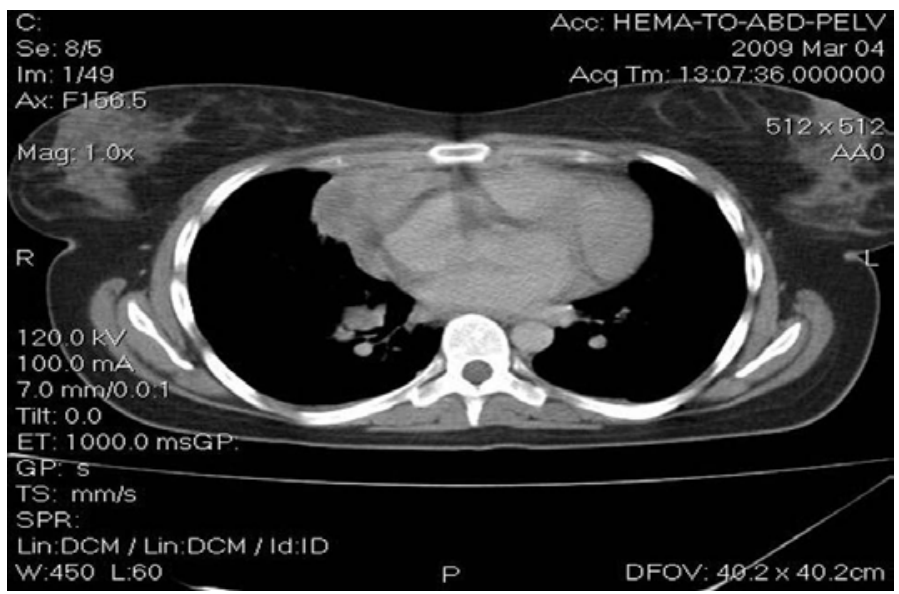

Figure 1. Large mediastinal mass of $10 \mathrm{~cm}$ in diameter with multiple metastatic lymph nodes localized around the mesenteric artery, the hepatic hilum, as well as the lombo-aortic artery and the common iliac arteries.

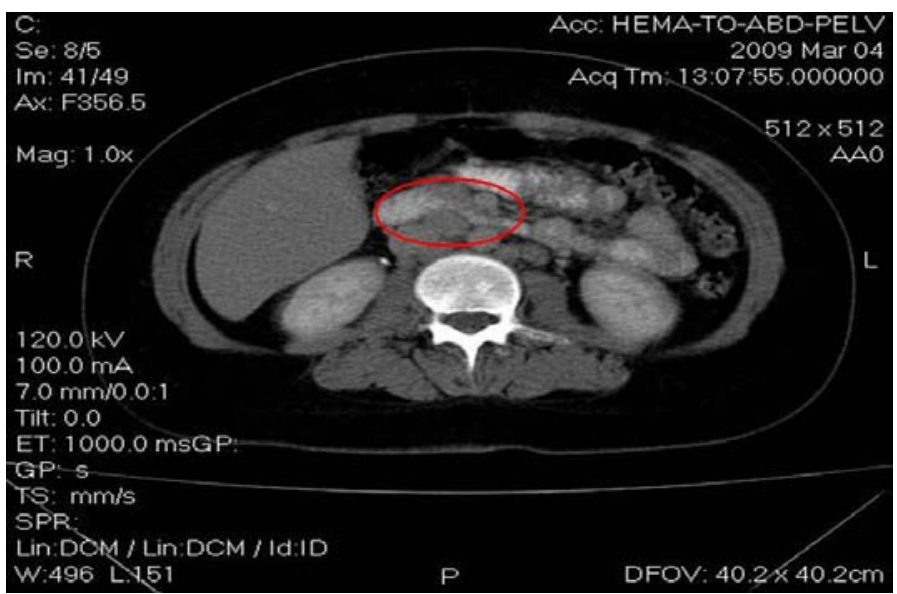

Figure 2A

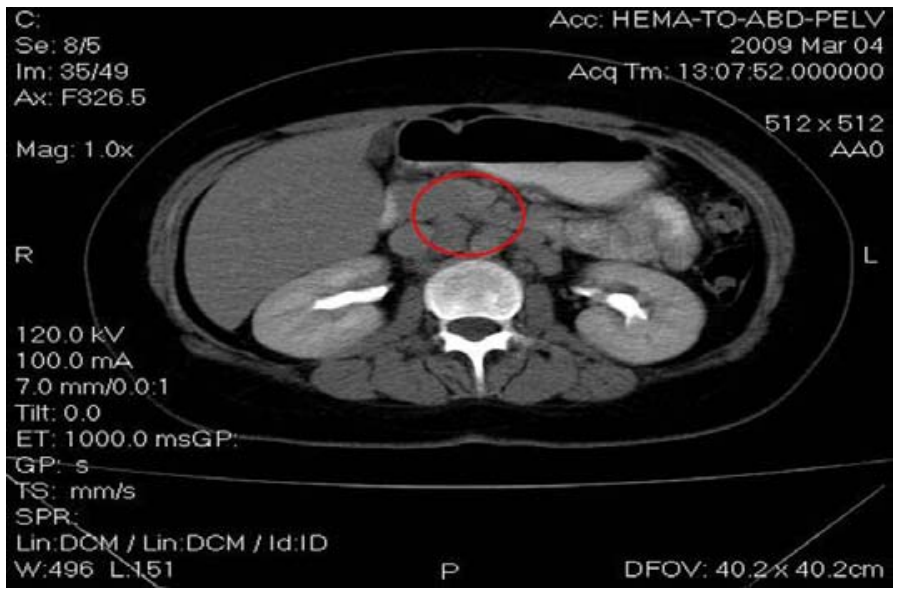

Figure 2B

Figures $2 \mathrm{~A}$ and $2 \mathrm{~B}$. Computer tomography shows sub-diaphragmatic metastatic lymph nodes and a persistent mediastinal mass. 


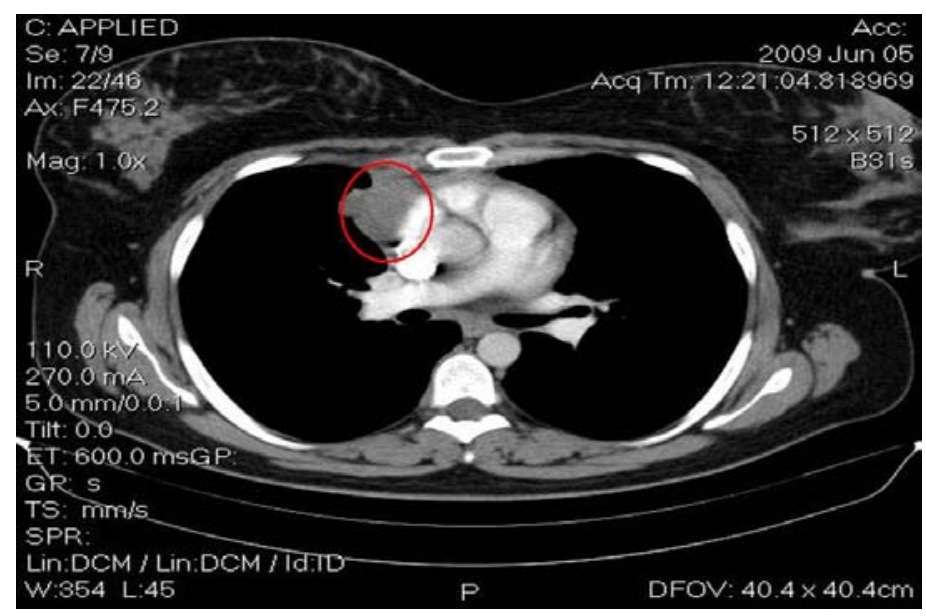

Figure 3. Positron emission tomography showing lymphoma relapse.

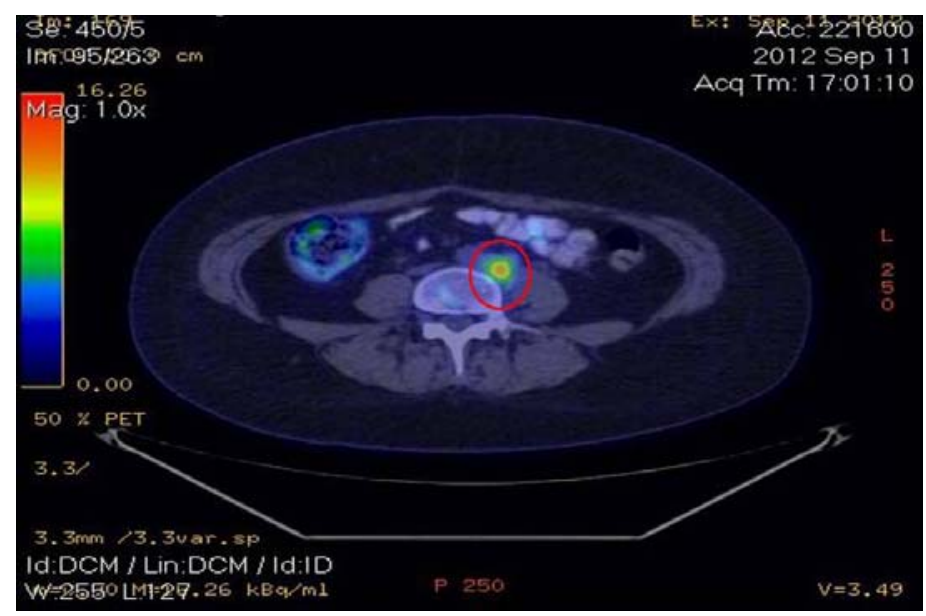

Figure 4. Positron emission tomography showing an increased metabolic activity in various sub-diaphragmatic lymph nodes, as well as in the left iliac crest.

The progressive disease required another transplant, this time a matched unrelated donor (MUD) allogeneic stem cell transplantation (alloSCT) and 2 cycles of salvage chemotherapy with gemcitabine and oxaliplatin was the only therapeutic option. BrentuximabVedotin was not used instead of gemcitabine and oxaliplatin because this drug was not found in Romania at the time. The CT Scan confirmed again the progressive disease before 9/10 HLA typing match was found in the International Bone Marrow Registry. Three cycles of chlorambucil, vinblastine, procarbazine and prednisolone (ChIVPP) were administered [12], but just before the transplant the donor was diagnosed with leukopenia and thrombocytopenia. Thus, the procedure was postponed.

Four months later, a PET Scan showed new bone lesions in the left iliac crest and in the vertebral bodies of L4 and L5, for which intensity modulated radiotherapy treatment (IMRT) with 35 Gy was done. At this point, it was obvious that the only curative treatment was a haploidentical stem cell transplantation.

\section{TRANSPLANTATION}

For the haploSCT, the donor was the mother of the patient, a 57-year old woman with 8/10 human leukocyte antigen (HLA) compatibility and a common haplotype with the patient. The donor had a AII Rh positive blood type, positive cytomegalovirus (CMV) IgG, negative HBS antigen, negative $\mathrm{HBS}$ antigen, negative anti-HCV antibodies and negative human immunodeficiency virus (HIV) infection, and negative Anti-HLA antibodies. The patient had a AII Rh positive blood type, positive CMV IgG, negative HBS antigen, negative HBS antigen, negative anti-HCV antibodies and negative HIV infection. Conditioning chemotherapy included melphalan $140 \mathrm{mg} / \mathrm{m}^{2}$ at day -8 and fludarabine $40 \mathrm{mg} / \mathrm{m}^{2}$ at days -5 to -3 .The patient rested at days -2 and -1 and then the donor stem cell infusion was 
done at day 0 without any incidents and with a TNC of $3.4 \times 10^{8}$ cells.

Post-transplant immunosuppression consisted of $50 \mathrm{mg} / \mathrm{kg} /$ day of cyclophosphamide at days +3 and +4 , tacrolimus $2 \mathrm{~g}$ /day starting with day +5 and $15 \mathrm{mg} / \mathrm{kg} /$ dose mycophenolate mofetil (MMF) p.o. TID to Day $+100.5 \mathrm{mcg} / \mathrm{kg}$ filgrastim was also administered starting with day +5 . Aplasia was diagnosed starting with day -1 , with $980 / \mathrm{mm}^{3}$ white blood cells (WBC), $9.1 \mathrm{~g} / \mathrm{dL}$ hemoglobin $(\mathrm{Hb})$ value and $11800 / \mathrm{mm}^{3}$ platelets (PLT). Complications included a grade III mucositis, and fever. Supportive care was done with meronem 1 every 8 hours and colistin every 8 hours, for 9 days. At day +15 , aplasia was overcome, with $8.6 \mathrm{~g} / \mathrm{dL} \mathrm{Hb}$ and $19000 / \mathrm{mm}^{3}$ PLT. 16 days post-haploSCT, a $100 \%$ donor chimerism was observed, confirming the success of the transplant.

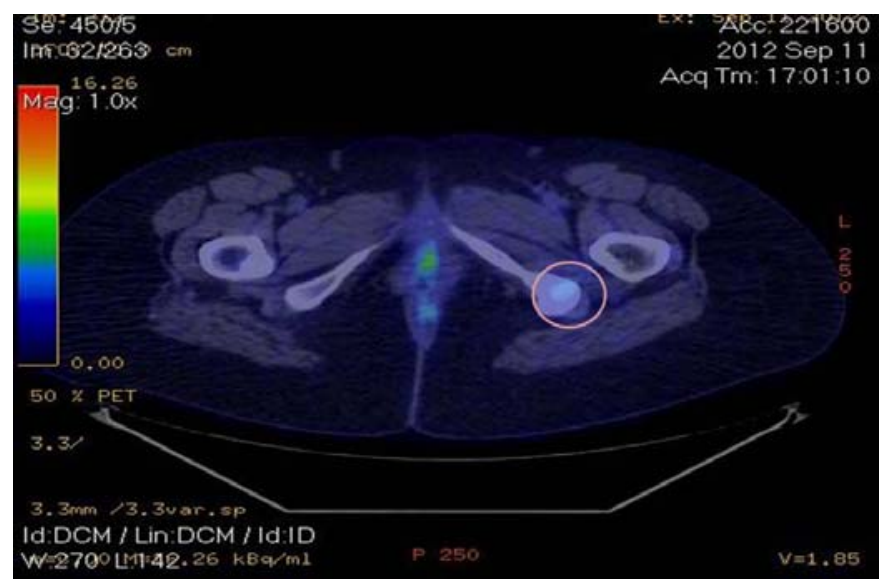

Figure $5 \mathrm{~A}$

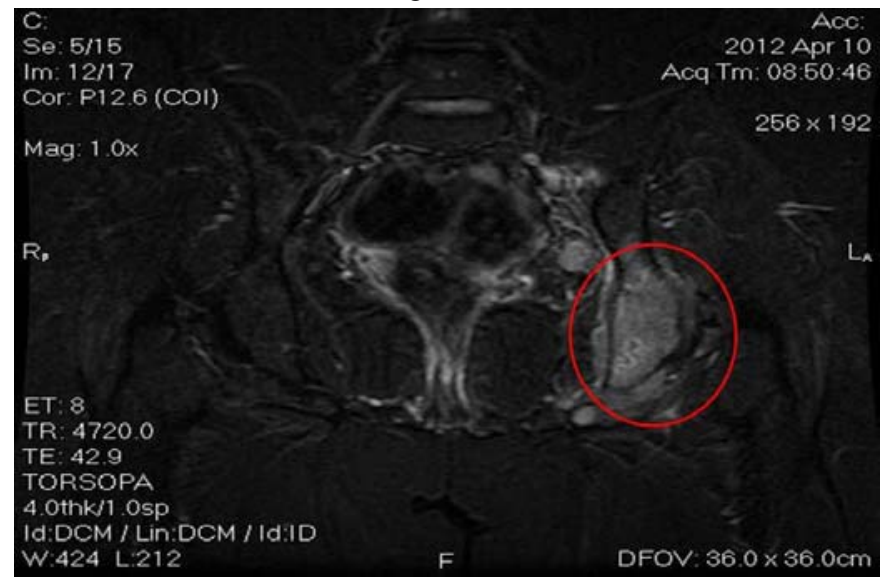

Figure 5B

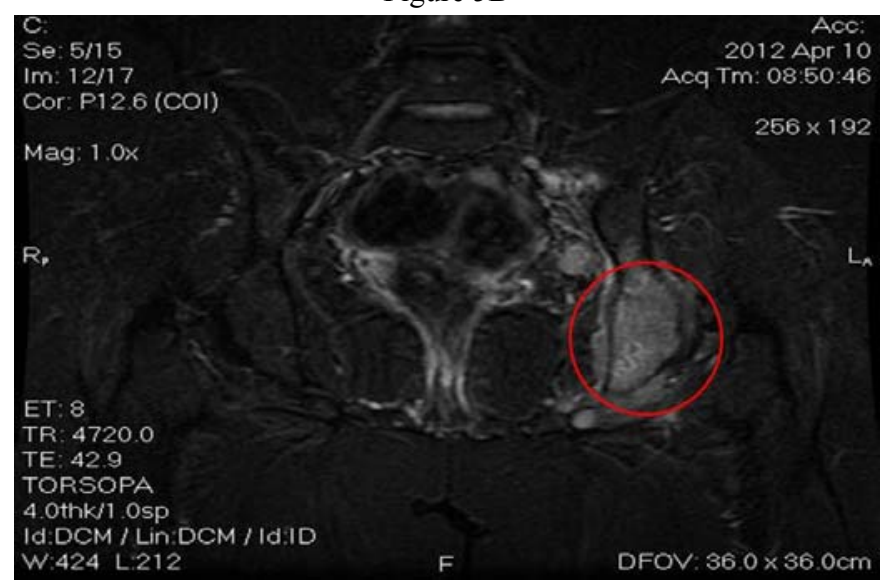

Figure 5C

Figure 5A, 5B and 5C. Active disease in the sub-diaphragmatic lymph nodes, confirmed later on by new bone lesions in the ischium, pubis and vertebrae. 


\section{DISCUSSION}

Finding a suitable donor is the main challenge for an allogeneic stem cell transplantation (allo$\mathrm{SCT}$ ). For up to $50 \%$ of all potential transplant patients, an HLA-matched sibling donor (MSD) or a HLA-matched unrelated donor (MUD) cannot be identified in time and the patient often relapses and dies from the hematological malignancy. On the other hand, a partially HLA-matched, also known as a HLA-haploidentical first degree relative, is a minor obstacle for the transplant hematologist as these potential HLA-haploidentical donors include the biological parents or children. Each of these potential donors have at least a $50 \%$ chance of sharing one HLA haplotype. The HLA haplotype is defined as the case when both the patient and the donor have exactly the same HLA alleles on chromosome 6 . The diagnosis is possible through high resolution typing for HLA-A, -B, -C, -DRB1 and -DQB1. A half-matched transplant was initially considered impossible to be implemented in the clinic because the $\mathrm{T}$ lymphocytes that respond to the allogeneic HLA molecules were responsible for the very high incidence of graft versus host disease (GVHD) and graft rejection, as reported by Powles et al. [13]. The patients enrolled in this study died from pulmonary edema, fever, fluid retention or kidney failure. This syndrome is known as engraftment syndrome, a diagnosis confirmed in another study by Beatty et al. [14].

For patients lacking a HLA-matched donor, the big question is whether haploSCT are a better or a worse therapeutic option in comparison with the double unrelated donor umbilical cord blood transplantation (dUCB). The Blood and Marrow Transplant Clinical Trials Network (BMT-CTN) have recently published the results of two parallel phase 2 trials of reduced intensity conditioning and either HLA-haploSCT with high dose post-transplant cyclophosphamide or dUCB transplantation [15]. The one year probabilities of overall survival (OS) or progression-free survival (PFS) were $54 \%$ and $46 \%$ for dUCB in comparison with $62 \%$ and $48 \%$ for haploSCT. The day 56 cumulative incidence of neutrophil recovery was $94 \%$ for dUCB and $96 \%$ for haploSCT, whereas the day incidence of GVHD was $40 \%$ for dUCB in comparison with $32 \%$ for haploSCT [16-18]. The quality of life after transplantation, apart from all the statistical data regarding survival, also suggests haploSCT as the best treatment available for leukemia or lymphoma patients that relapse after standard chemotherapy or after an autologous SCT and for which a matched donor cannot be found.

Transplantation of haploidentical stem cells is becoming a well-established approach in lymphoma patients, which makes a potential donor available for almost all patients. CD34+ positive selection has been the most common procedure for graft manipulation in the past years, whereas $\mathrm{T}$ and $\mathrm{B}$ cell depletion is a promising new method. GVHD could herewith be effectively reduced and primary engraftment was reported in $83-100 \%$ of patients after transplantation of high stem cell doses. For patients with lymphomas in remission, disease-free survival at 3 years ranged between 22 and $48 \%$. Treatment-related mortality, mainly because of viral infections, was improved by the use of reducedintensity conditioning (which helped to speed up $\mathrm{T}$ cell recovery) and by close monitoring of viral loads and prophylactic/preemptive therapy. The role of donor-derived Ag-specific $\mathrm{T}$ cells against viral and fungal antigens is currently under investigation. Patients with active disease at the time of transplantation had a poor outcome and several attempts to improve these results are currently evaluated, such as co-infusion of natural killer cells, co-transplantation of mesenchymal stem cells, use of new drugs and post-transplant cyclophosphamide [19]. Outcomes in haploidentical stem cell transplantations have improved and outcomes are comparable to matched transplants, both for hematological malignancies, as well as for other conditions [20]. In a seminal paper, Bashey et al. have compared in Atlanta retrospectively 271 patients that have underwent an allogeneic stem cell transplant, out of which 100 had received a MSD, 101 a MUD and 53 a haploidentical transplant. GVHD prophylaxis consisted of post-transplantation cyclophosphamide, tacrolimus and MMF for the haploSCT cases, while the matched transplantations had received conventional treatment for GVHD. For MSD, MUD and haploSCT cases, the 2-year cumulative incidence of NRM was $13 \%, 16 \%$ and respectively $7 \%$, while relapse was similar (34\% vs $34 \%$ vs 33\%). The 2-year disease-free survival was $53 \%, 52 \%$ and $60 \%$ [21]. The transplant unit from MD Anderson Cancer Center in the United States have analyzed the outcomes of 227 patients treated with fludarabine $120-160 \mathrm{mg} / \mathrm{m}^{2}$, melphalan 100 $140 \mathrm{mg} / \mathrm{m}^{2}$ and thiotepa $5-10 \mathrm{mg} / \mathrm{kg}$, for the haploidentical cases. 87 underwent a MSD, 108 a MUD and 18 of them a haploSCT transplant. For the matched donors, GVHD prophylaxis was done with tacrolimus and mini-methotrexate with thymo- 
globulin in MUDs, whereas the haploSCT cases had received PTCy, tacrolimus and MMF. MSD, MUDs and haploSCT cases had similar grade II-IV acute GVHD $(24 \%, 19 \%$, and $26 \%)$ for the ones in remission, whereas severe acute GVHD was reported to be of $4 \%, 4 \%$ and respectively $0 \%$. PFS at 3 years was concluded to be similar $(57 \%, 45 \%$, and $41 \%$ ) but a significant trend towards a better 3 -year progression-free survival was reported in those with a matched sibling donor [22]. Thus, almost identical results are between haploSCT transplants and the matched ones, for both lymphoid and myeloid malignancies, mostly due to various conditioning chemotherapy regimens. HaploSCT are even more important taking into consideration that in Romania, transplant centers do not have access to a public cord blood bank and thus, a HLA-half-matched donor may be the life-saving solution for patients diagnosed with various hematologic malignancies.

As haploSCT are emerging as the best treatments available, in the current case report we emphasize the need to continue this trend in stem cell transplantation and offer patients diagnosed with various hematological malignancies in Romania as well as in Eastern Europe the possibility of a haploSCT, as we have already cured our first case.

\section{CONCLUSIONS}

A conditioning chemotherapy regimen based on post-transplant cyclophosphamide is a reduced intensity conditioning regimen. This regimen is used mostly for patients diagnosed with aggressive lymphoproliferative diseases. Hodgkin's lymphomas and aggressive lymphomas are usually cured after the first line of chemotherapy, but around half of them relapse or have a progressive disease, usually cured by high dose chemotherapy and autologous stem cell transplantation. Still, a large number of patients need further therapy and classic myeloablative regimens for allogeneic stem cell transplantation have been associated with disappointing results due to a high non-relapse mortality, as well as due to the lack of a HLA-compatible donor for most cases. Thus, one solution was the use of a haploidentical T-cell repleted stem cell transplantation, as is the case of the present patient. Without a haploidentical stem cell transplantation, the prognosis would have been dismal, but by using the protocol described in the current paper the patient is disease-free one year after the transplant.

Transplantul hematopoietic de celule stem reprezintă un tratament standard pentru multe afecțiuni hematologice, atât neoplazice cât şi benigne. În prezenta lucrare, descriem aplicarea transplantului haploidentic de celule stem hematopoietice pentru prima dată în România. Este descris cazul unei paciente de 33 de ani diagnosticate cu limfom Hodgkin, ce a beneficiat de un transplant haploidentic după ce a recidivat în urma a multiple cure de chimioterapie, dar şi în urma unui transplant autolog de celule stem. Acest succes reprezintă o premieră în hematologia clinică românească, fiind primul caz de transplant haploidentic din țară şi chiar din sud-estul Europei.

Correspondence to: CiprianTomuleasa, $\mathrm{MD}, \mathrm{PhD}$

"Iuliu Hațieganu" University of Medicine and Pharmacy, Cluj-Napoca, Romania

Department of Hematology, "Ion Chiricuță” Oncology Institute, Cluj-Napoca, Romania

Bulevardul 21 Decembrie 1918, Nr. 73, 400124, Cluj-Napoca, Romania

Telephone: 004-0741337480

E-mail: ciprian.tomuleasa@umfcluj.ro

\section{REFERENCES}

1. GYURKOCZA B., REZVANI A., STORB RF. Allogeneic hematopoietic cell transplantation: the state-of-the-art. Expert Rev Hematol. 2010; 3(3):285-99.

2. BARON F., STORB R. Allogeneic hematopoietic cell transplantation as treatment for hematological malignancies: a review. Springer Semin Immunopathol. 2004; 26(1-2):71-94.

3. BARONF., STORB R., LITTLE MT. Hematopoietic cell transplantation: five decades of progress. Arch Med Res. 2003; 34(6):528-44. 
4. STAAL F.J., BAUM C., COWAN C., DZIERZAK E., HACEIN-BEY-ABINA S., KARLSSON S., et al. Stem cell self-renewal: lessons from bone marrow, gut and iPS toward clinical applications. Leukemia. 2011; 25(7):1095-102.

5. SAULNIER N., DI CAMPLI C., ZOCCO M.A., DI GIOCCHINNO G., NOVI M., GASPARRINI A. From stem cell to solid organ. Bone marrow, peripheral blood or umbilical cord blood as favorable source? Eur Rev Med Pharmacol Sci. 2005; 9(6):315-24.

6. CANELLOS G.P., ANDERSSON J.R., PROPERT K.J., NISSE N., COOPER M.R., HENDERSSON E.S., et al. Chemotherapy of advanced Hodgkin's disease with MOPP, ABVD, or MOPP alternating with ABVD. N Engl J Med. 1992; 327(21):1478-84.

7. DIEHL V., FRANKLIN J., PFEUNDSCHUCH M., LATHAN B., PAULUS U., HASENCLEVER D., et al. Standard and increased-dose BEACOPP chemotherapy compared with COPP-ABVD for advanced Hodgkin's disease. N Engl J Med. 2003; 348(24):2386-95.

8. SANTORO A., MAGAGNOLI M., SPINA M., PINOTTI G., SIRACUSANO L., MICHIELI M., et al. Ifosfamide, gemcitabine, and vinorelbine: a new induction regimen for refractory and relapsed Hodgkin's lymphoma. Haematologica. 2007; 92(1):35-41.

9. JOSTING A., RUDOLPH C., MAPARA M., GLOSSMANN J.P., SIENIAWSKI M., SIEBER M., et al. Cologne high-dose sequential chemotherapy in relapsed and refractory Hodgkin lymphoma: results of a large multicenter study of the German Hodgkin Lymphoma Study Group (GHSG). Ann Oncol. 2005; 16(1):116-23.

10. GLOSSMANN J.P., STAAK J.O., NOGOVA L., DIEHL V., SCHEID C., KISRO J., et al. Autologous tandem transplantation in patients with primary progressive or relapsed/refractory lymphoma. Ann Hematol. 2005; 84(8):517-25.

11. JOSTING A., NOGOVA L., FRANKLIN J., GLOSSMANN J.P., EICH H.T., SIEBER M., et al. Salvage radiotherapy in patients with relapsed and refractory Hodgkin's lymphoma: a retrospective analysis from the German Hodgkin Lymphoma Study Group. J ClinOncol. 2005; 23(7):1522-9.

12. SELBY P., PATEL P., MILAN S., MELDRUM M., MANSI J., MBIDDE E., et al. ChlvPP combination chemotherapy for Hodgkin's disease: long-term results. Br J Cancer. 1990; 62(2):279-85.

13. POWLES R.L., MORGENSTERN G.R., KAY H.E., MCELWAIN T.J., CLINK H.M., DADY P.J.. et al. Mismatched family donors for bone-marrow transplantation as treatment for acute leukaemia. Lancet. 1983; 1(8325):612-5.

14. BEATTY P.G., CLIFT R.A., MICKELSON E.M., NISPEROS B.B., FLOURNOY N., MARTIN P.J., et al. Marrow transplantation from related donors other than HLA-identical siblings. N Engl J Med. 1985; 313(13):765-71.

15. BRUNSTEIN C.G.,FUCHS E.J., CARTER S.L., KARANES C., COSTA L.J., WU J., et al. Alternative donor transplantation after reduced intensity conditioning: results of parallel phase 2 trials using partially HLA-mismatched related bone marrow or unrelated double umbilical cord blood grafts. Blood. 2011; 118(2):282-8.

16. AL MALKI M.M., HOROWITZ M., HANDGRETINGER R., LEUNG W., ROY D.C., HUANG X.J., et al. Proceedings from the Second Haploidentical Stem-cell Transplantation Symposium - Haplo2014, San Francisco, California, December 4, 2014. Biol Blood Marrow Transplant. 2016; S1083-8791(16)00004-5.

17. KANATE A.S., MUSSETTI A., KHARFAN-DABAJA M.A., AHN K.W., DI GILIO A., BEITINJANEH A., et al. Reducedintensity transplantation for lymphomas using haploidentical related donors versus HLA-matched unrelated donors. Blood. 2016; in press.

18. BAYRAKTAR U.D., MILTON D.R., GUINDANI M., RONDON G., CHEN J., AL-ATRASH G., et al. Optimal Threshold and Time of Absolute Lymphocyte Count Assessment for Outcome Prediction after Bone Marrow Transplantation. Biol Blood Marrow Transplant. 2015; S1083-8791(15)00709-0.

19. BRAMMER J.E., KHOURI I., GABALLA S., ANDERLINI P., TOMULEASA C., AHMED S., et al. Outcomes of Haploidentical Stem Cell Transplantation for Lymphoma with Melphalan-Based Conditioning. Biol Blood Marrow Transplant. 2015: S1083-8791(15)00685-0.

20. O’DONNEL P.V., LUZNIK L., JONES R.J., VOGELSANG G.B., LEFFEL M.S., PHELPS M., et al. Nonmyeloablative bone marrow transplantation from partially HLA-mismatched related donors using posttransplantation cyclophosphamide. Biol Blood Marrow Transplant. 2002; 8(7):377-86.

21. BASHEY A., ZHANG X., SIZEMORE C.A., MANION K., BROWN S., HOLLAND H.K., et al. T-cell-replete HLAhaploidentical hematopoietic transplantation for hematologic malignancies using post-transplantation cyclophosphamide results in outcomes equivalent to those of contemporaneous HLA-matched related and unrelated donor transplantation. J Clin Oncol. 2013;31(10):1310-6.

22. DI STASI A., MILTON D.R., POON L.M., HAMDI A., RONDON G., CHEN J., et al. Similar transplantation outcomes for acute myeloid leukemia and myelodysplastic syndrome patients with haploidentical versus 10/10 human leukocyte antigenmatched unrelated and related donors. Biol Blood Marrow Transplant. 2014; 20(12):1975-81.

Received December 14, 2015 